\title{
Allogeneic bone marrow transplantation for severe aplastic anemia patients with risk factors for poor prognosis: is fludarabine a requirement?
}

\author{
Transplante alogênico de medula óssea em portadores de anemia aplásica severa com fatores de \\ mau prognóstico: é necessário fludarabina?
}

\author{
Carlos R. de Medeiros \\ Elenaide Coutinho \\ Eliane R. Carmes \\ Marco A. Bitencourt \\ Jefferson Ruiz \\ Carmen S. Bonfim \\ Vaneusa M. Funke \\ Daniela C. Setubal \\ José Zanis-Neto \\ Ricardo Pasquini
}

\begin{abstract}
Hematopoietic progenitor cell transplantation from HLA-identical sibling donors cures 70-90\% of Severe Aplastic Anemia (sAA) patients. Older age, heavy exposure to transfusions, immunosuppression treatment (IST) with a long interval from diagnosis to transplant and infection at procedure are associated with poor outcomes. We transplanted 18 patients with $S A A$ and at least one risk factor $(R F)$ for poor prognosis (age $>35$ years, $>50$ transfusions prior to transplant, unresponsiveness to previous IST and bacterial or fungal infection at transplant) from 2001 to 2005, using cyclophosphamide (CY - 5 patients) or busulfan plus CY (13 patients). Sixteen patients engrafted, two died with no engraftment, three patients had evidence of graft failure at days $+67,+524$ and +638 (two died and one was rescued with IST). Grade III/IV mucositis occurred in 39\% but neither a GVHD nor c GVHD were observed. The KaplanMeier probability of survival was $75 \%$ at 2.14 years, with a trend favoring survival by number of $R F(1$ versus $=2 R F)(P=0.06)$. These results are comparable to recent data reported with fludarabine-based conditioning in patients with poor prognosis $S A A$. Due to the small sample size, prospective clinical trials with larger cohorts of patients are needed to confirm the real benefits offludarabine-based conditioning, and also to define the best agent(s) to be associated with Fludarabine as preparative regimen for sAA patients with poor prognosis. Rev. bras. hematol. hemoter. 2008; 30(4):292-296.
\end{abstract}

Key words: Severe aplastic anemia; fludarabine-based conditioning; poor prognosis sAA; graft failure.

\section{Introduction}

Hematopoietic progenitor cell transplantation (HPCT) from an HLA-identical sibling donor is the curative treatment for 70 to $90 \%$ of Severe Aplastic Anemia patients (sAA). ${ }^{1}$ However, older age, long duration of disease with consequent heavy exposures to transfusion and active infection at time of HPCT have a negative influence on outcome, favoring graft failure (GF) and quite probably graft versus host disease (GVHD). ${ }^{2}$ Several patients with sAA, even those with an HLAidentical available donor, have been considered unsuitable for this procedure, due to the presence of these risk factors for poor survival. Immunosuppression (IST), in spite of being a non-curative treatment for sAA patients, may promote partial recovery of hematopoiesis, and has been used as an alternative for patients with an available donor but presenting poor survival risk factors at the time of HPCT. ${ }^{3}$ Unfortunately, $\sim 35 \%$ of IST treated patients do not respond and another therapeutic approach is then needed.

Nonmyeloablative HPCT (NMHPCT) has been successfully used in the treatment of hematological malignancies. Older age, pretransplantation comorbidities and extensive previous treatments are the main factors leading to the use of less aggressive conditioning regimens. ${ }^{4}$

Bone Marrow Transplantation Service, Hospital de Clínicas, Universidade Federal do Paraná (UFPR) - Curitiba-PR.

Correspondence: Carlos R. de Medeiros

Bone Marrow Transplantation Service, Hospital de Clínicas, UFPR

Rua General Carneiro, $181-15^{\circ}$ andar

Zip code 80060-900 - Curitiba-PR - Brazil

Phone: 55 41-33361110; Fax: 55 41-33361110

E-mail: crdemedeiros@terra.com.br 
Fludarabine (FLU), a nonmyeloablative immunosuppressant with mild systemic activity, has been used as part of conditioning regimens in allogeneic NMHPCT, allowing engraftment of patients with hematological malignancies, even when the donor is unrelated. When compared to conventional conditioning regimens, at least in patients with hematological malignancies, NMHPCT has promoted engraftment with less toxicity and a lower incidence of acute (a) GVHD. ${ }^{5}$ Early in 2000, several case reports demonstrated the feasibility of FLU-based regimens used as conditioning for HPCT, allowing long-lasting engraftment with low regimen-related toxicity for non-malignant hematological conditions. ${ }^{6-10}$

Before embarking on a new protocol involving FLU as part of conditioning to treat sAA patients with poor survival risk factors, we decided to analyze our transplant results with conventional (CONV) conditioning. Herein we describe the outcomes of sAA patients, who had at least one risk factor for poor survival at the time of procedure, transplanted from 2001 to 2005 using an alkylating agent alone (cyclophosphamide - CY) or in combination (busulfan and $\mathrm{CY}$ ).

\section{Patients and Method}

Patients with sAA were included in our HPCT protocol from January 2001 to June 2005 with all receiving unmanipulated bone marrow from an HLA-identical sibling donor. Patients were eligible for analysis if they presented at least one of the following risk factors: (1) age older than 35 years; (2) $>50$ transfusions prior to transplant; (3) defined or probable invasive fungal infection and/or confirmed bacterial infection at transplant; (4) unresponsiveness to IST prior to transplant. Median age of participants was 18.2 years (range 6 to 46 years) with ten patients being male.

Conditioning regimen was $50 \mathrm{mg} / \mathrm{kg} \mathrm{CY}$ once daily i.v. on days 1 to 4 (total dose $200 \mathrm{mg} / \mathrm{kg}-5$ patients) or $3 \mathrm{mg} / \mathrm{kg}$ BU p.o. in divided doses daily for 4 days (total dose $12 \mathrm{mg} /$ $\mathrm{kg}$ ) plus CY $60 \mathrm{mg} / \mathrm{kg}$ once daily i.v. on days 1 and 2 (total dose $120 \mathrm{mg} / \mathrm{kg}-13$ patients). Patients were isolated in single or double rooms with high efficiency particulate air filters. In case of ABO incompatibility, red blood cells or plasma were removed by starch sedimentation. Patients seronegative for cytomegalovirus (CMV) were transfused with CMV-negative blood or leukodepleted blood. Acyclovir prophylaxis were used for the herpes virus and trimethropim-sulfamethoxazole for Pneumocystis carinii for all patients as was fluconazole for fungus prevention. Weekly antigenemia, to monitor CMV viremia, and preemptive treatment with ganciclovir were routine. Grade II to IV acute (a) GVHD was defined using published criteria ${ }^{11}$ and patients surviving $>28$ days posttransplant with engraftment were considered to be at risk. Patients engrafted and surviving $>90$ days were at risk for chronic (c) GVHD. ${ }^{12}$ Neutrophil engraftment was defined as an absolute neutrophil count $>0.5 \times 10^{9} / \mathrm{L}$ on at least two consecutive days without treatment using a growth factor. Time to platelet engraftment was defined as three consecutive days on which the platelet count was higher than $50 \times 10^{9} / \mathrm{L}$ without transfusion for seven days. GF was classified as primary graft failure when no hematological recovery in patients surviving $>28$ days post-transplant occurred; and as transient engraftment (TE) when complete or partial recovery of hematopoiesis of donor origin was detected, followed by recurrent pancytopenia with markedly hypocellular marrow in the absence of GVHD. Documented marrow donor engraftment was confirmed by ABO typing in patients with major red blood cell group differences, by chromosomal analysis for sex-mismatched patient/donor pairs and by PCR targeting a variable number of tandem repeats loci. Prophylaxis for graft versus host disease was identical for all patients using Methotrexate and Cyclosporine. The protocol was approved by the Ethics Committee of the Hospital de Clinicas and all patients or parents gave written informed consent. Typing of both donor and recipient pairs involved low resolution for class I HLA by reverse sequence specific oligonucleotides using Luminex technology (One Lambda Cat. RSSO1A/RSSO1B, Canoga Park, USA), and high resolution for class II HLA using sequence specific primers (One Lambda Cat. SSP2H, Canoga Park, USA).

\section{Results}

Eighteen patients with sAA and, at least, one poor prognostic risk factor were included in our HPCT protocol from January 2001 to June 2005. The baseline characteristics of patients are shown in Table 1. Sixteen patients engrafted and two died on days +10 (septic shock) and +22 (central

Table 1. Baseline characteristics of 18 patients

\begin{tabular}{|c|c|}
\hline Number of patients [n (\%)] & $18(100)$ \\
\hline $\begin{array}{l}\text { Sex } \\
\quad \text { male }[n(\%)]\end{array}$ & $10(56)$ \\
\hline $\begin{array}{l}\text { Age in years [median (range)] } \\
\quad>35 \text { years }[\mathrm{n}(\%)]\end{array}$ & $\begin{array}{l}18.2 \pm 9.4(6-46) \\
1(6)\end{array}$ \\
\hline Infection at HPCT [n (\%)] & $4(22)$ \\
\hline Previous IST [n (\%)] & $16(89)$ \\
\hline $\begin{array}{l}\text { Prior transfusion } \\
\text { [median (range) } \\
\quad>50(\%)\end{array}$ & $\begin{aligned} 27 & (6-51) \\
2 & (11)\end{aligned}$ \\
\hline $\begin{array}{l}\text { Interval DX ? HPCT months } \\
\quad \text { [median (range) }\end{array}$ & $5.5(1-47)$ \\
\hline $\begin{array}{l}\text { Risk factors [n (\%)] } \\
\quad 1 \\
\quad \geq 2\end{array}$ & $\begin{array}{r}15(83) \\
3(17)\end{array}$ \\
\hline Cell dose $\times 10^{8} / \mathrm{kg}$ & $1.9-6.6$ (M: 3.4$)$ \\
\hline
\end{tabular}


nervous system fungal infection) with no engraftment. Three patients had only TE with subsequent GF on days +67 , +524 and +638 . The former two died secondary to fungal infection and central nervous system bleeding, respectively, and the latter was rescued with maintenance IST. Grade 0/II mucositis was observed in 11 patients $(61 \%)$, and grade III/ IV in 7 patients $(39 \%)$. Neither aGVHD nor cGVHD were presented by our patients. Fourteen patients survived the

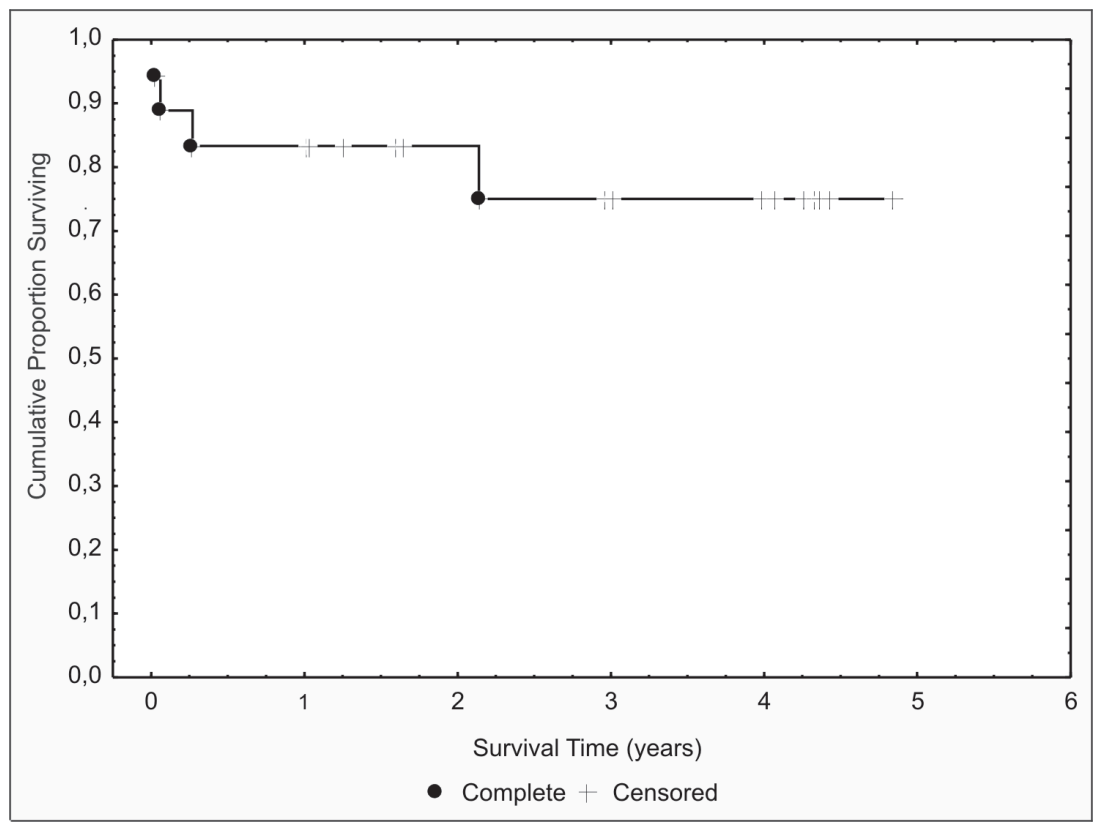

Figure 1 - Cumulative probability of survival $(n=18)$

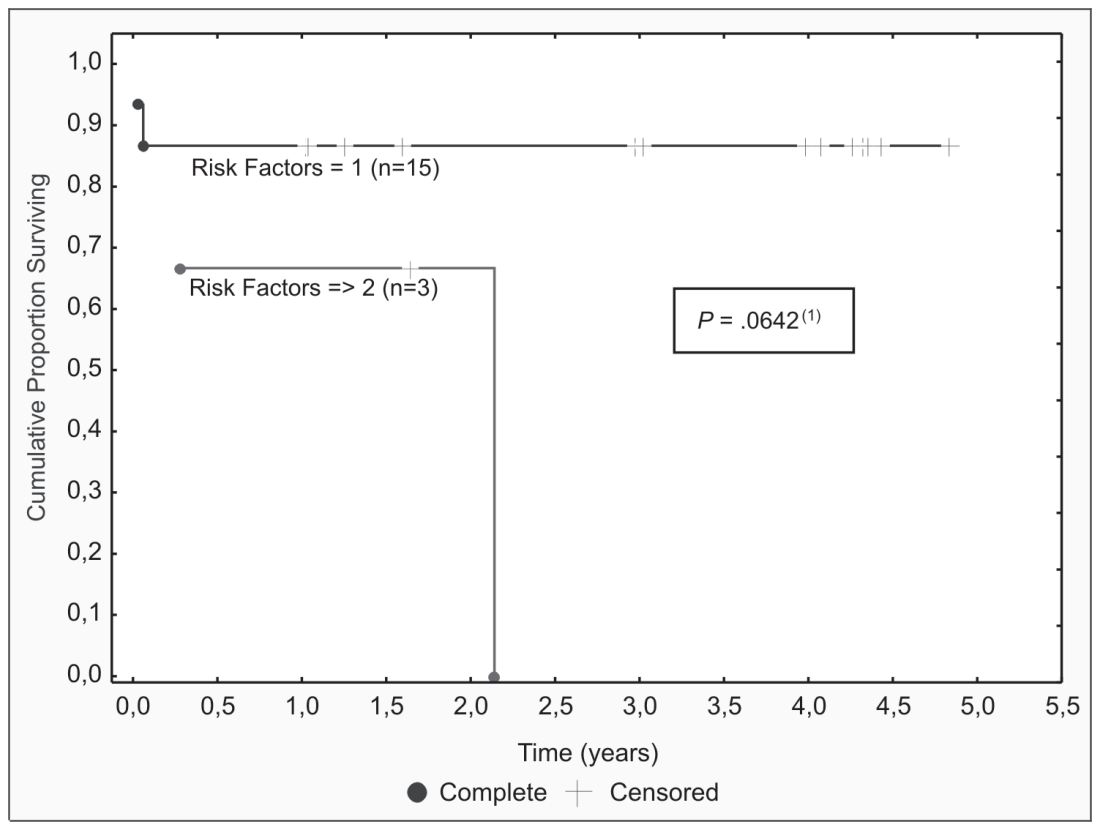

Figure 2 - cumulative probability of survival stratified by risk factors procedure, hence the probability of survival calculated by the Kaplan-Meier method was $75 \%$ at 2.14 years (Figure 1). When we compared survival by number of risk factors (1 versus $\geq 2$ risk factors), we observed a trend for better survival of patients with only one risk factor at transplant $(P=0.06)$. (Figure 2$)$. Survival of patients with only one risk factor determined by Kaplan-Meier was $85 \%$ at 2.14 years.

\section{Statistical analysis}

Demographic, clinical and laboratory data are summarized in Table 1 using percentages, means and standard deviation or median and range values. The ShapiroWilk $\mathrm{W}$ test is used to test for normality. If the $\mathrm{W}$ statistic is significant, then the hypothesis that the respective distribution is normal should be rejected. GF was analyzed in patients surviving at least 28 days post-transplantation. Patients surviving 28 days with engraftment were considered at risk for aGVHD and those surviving 90 days, for cGVHD. Survival curves were calculated using the Kaplan-Meier product limit method. The log-rank test was used to test differences in survival. All Pvalues presented are 2 -sided. A probability below 0.05 was considered significant. Statistical analyses were carried out using the Statistica 7.0 (StatSoft, Inc, Tulsa, OK, USA) software.

\section{Discussion}

Several risk factors negatively influence survival of sAA patients treated with allogeneic HPCT. Older age for reasons not completely understood, exposure to a large number of transfusions due to sensitization of the recipient to histocompatibility antigens, and long duration of disease are recognized as risk factors for GF, a major procedure problem. In addition, low neutrophil and monocyte counts put sAA patients at risk for bacterial and fungal infections ${ }^{13}$ and worse HPCT results are expected when performed in the presence of an infectious process. Also, patients undergoing HPCT after failing IST have usually been heavily transfused and are inclined to acquire bacterial and fungal infections, thereby affecting survival. ${ }^{14}$

Increasing of conditioning regimens has been a strategy to reduce GF. ${ }^{15}$ Incorporation of total body irradiation (TBI) 
to conditioning has overcome the risk of graft rejection, but leads to several complications. High doses or the combination of alkylating agents may reduce GF but generally with no better outcome in heavily transfused patients. ${ }^{16}$ In addition, more toxicity at conditioning is undesirable for patients with past or present bacterial and/ or fungal infections at transplant. Fludarabine, as has been demonstrated in NMHPCT to treat malignancies, as a useful drug capable of immunoablation. This medication when associated to low doses of an alkylating agent with or without antithymocyte globulin (ATG) and low-dose TBI, should create the desired conditioning regimen: high immunosuppression and low toxicity.

Recently, four groups published their experience with HPCT in patients with marrow failure syndromes and increased graft failure risk using a FLU-based conditioning regimen. ${ }^{17-20}$ Kumar et al. ${ }^{17}$ transplanted five sAA patients with PBSC from HLA-identical sibling donors, conditioned with FLU, CY and ATG. GVHD prophylaxis was by cyclosporine (CSA). At a median follow-up of 171 days, all patients had engrafted with no rejection; aGVHD was present in one and cGVHD in two patients. Resnick et al. ${ }^{18}$ published the results of 13 sAA patients receiving PBSC cells from a family matched donor. Conditioning was by FLU, CY and ATG and prevention of GVHD used CSA and methotrexate (MTX). Twelve patients achieved sustained engraftment, cumulative aGVHD was $8.3 \%$, only one patient evolved with limited cGVHD, and with a median follow-up of 45 months, the 5-year overall probability of survival was $84 \%$. Ramaprasad et al. ${ }^{19}$ treated 26 patients with marrow failure syndromes (sAA, pure red cell aplasia and paroxysmal nocturnal hemoglobinuria) with HPCT from a HLA-compatible relative. Conditioning was by FLU and CY with or without ATG, and CSA alone or with mycophenolate mofetil or MTX were used as GVHD prophylaxis. All patients achieved durable engraftment and transfusion-independence, but cumulative aGVHD and cGVHD were $65 \%$ and $56 \%$ respectively; 24 patients are alive at a median of 21 months following transplantation (Kaplan-Meier estimate of overall survival was $77 \%$ ). Finally, Gomez-Almaguer et al. ${ }^{20}$ transplanted 23 sAA patients, previously unresponsive to IST, with PBSC from a sibling donor. Conditioning used FLU, CY and BU and GVHD prophylaxis was CSA and MTX. Twenty-one patients engrafted and 19 remain in complete remission (two after a second infusion of PBSC). aGVHD occurred in four and limited cGVHD in six patients.

In contrast, over 17 months we transplanted 18 sAA patients with at least one risk factor for poor prognosis, utilizing $\mathrm{CY}$ alone or $\mathrm{BU}+\mathrm{CY}$ as preparative regimen, both recognized as nonmyeloablative conditioning, with 14 patients remaining alive (Kaplan-Meier survival is $75 \%$ at 2.14 years). TE occurred in three patients, one was rescued with maintenance of IST and the other two died secondary to fungal and bacterial infections, respectively. We also noticed a possible relationship between number of risk factors and survival. Our patients presenting with one risk factor had a trend for better survival compared to patients with $\geq 2$ risk factors $(P=0.07)$. Kaplan-Meier survival of patients with only one risk factor was $85 \%$ at 2.14 years. We neither observed aGVHD nor cGVHD, contrasting with the data of Ramaprasad et al.,${ }^{19}$ who described $65 \%$ of grade II-IV aGVHD and $65 \%$ of cGVHD among their patients. So, with a CONV conditioning our results are very similar to those recently published utilizing FLU, at least in patients with one risk factor for poor survival.

Prospective clinical trials with larger cohorts of patients are needed, to establish the real benefits of FLU-based conditioning regimens and also to define the best agent(s) to be associated with FLU, when transplanting sAA patients with risk factors for poor prognosis.

\section{Resumo}

Transplante de medula óssea de doador irmão HLA-idêntico pode curar 70\%-90\% dos portadores de anemia aplásica severa (AAs). Pacientes mais idosos, muito transfundidos, longamente tratados com imunossupressão (IS) e com infecções ao tempo do transplante têm pior evolução. Nós transplantamos 18 pacientes com AAs e pelo menos um dos fatores associados a pior prognóstico (idade $>35$ anos, >50 transfusões antes do transplante, falta de resposta à imunossupressão prévia e infecção bacteriana ou fúngica ao transplante) de 2001 a 2005, com ciclofosfamida (Cy - 5 pacientes) ou bussulfan mais Cy (13 pacientes). Dezesseis pacientes apresentaram pega do enxerto, dois morreram sem pega, três tiveram rejeição aos dias $+67,+524$ e +638 (dois morreram e um foi resgatado com IS). Mucosite grau III/IV ocorreu em $39 \%$ e não observamos DECH aguda ou crônica. A probabilidade de sobrevida pelo método de Kaplan-Meier foi de 75\% aos 2,14 anos, e uma tendência a melhor sobrevida foi encontrada entre os portadores de apenas um fator de risco ao transplante (P: .06). Estes resultados são comparáveis a recentes relatos de literatura envolvendo condicionamentos baseados em fludarabina para tratar pacientes com alto risco. Devido à pequena amostra analisada, estudos clínicos prospectivos com maior número de pacientes são necessários, visando comprovar o real beneficio dos condicionamentos baseados em fludarabina, definir o melhor agente a ser a ela associado e assim obter o melhor condicionamento para portadores de AAs com fatores de mau prognóstico para o transplante. Rev. bras. hematol. hemoter. 2008; 30(4):292-296.

Palavras-chave: Anemia aplásica severa; condicionamento baseado em fludarabina; AAs de mau prognóstico; falha de pega.

\section{Acknowledgments}

The authors are indebted to Miss Heliz R. Neves, our data manager, for her excellent contribution. 


\section{References}

1. Stucki A, Leisenring W, Sandmaier BM, Sanders J, Anasetti C, Storb R. Decreased rejection and improved survival of first and second marrow transplantations for severe aplastic anemia (a 26year retrospective analysis). Blood. 1998;92(8):2742-9.

2. Champlin RE, Horowitz MM, van Bekkum DW, Camitta BM, Elfenbein GE, Gale RP, et al. Graft failure following bone marrow transplantation for severe aplastic anemia: risk factors and treatment results. Blood. 1989;73(2):606-13.

3. Doney K, Leisenring W, Storb R, Appelbaum FR. Primary treatment of acquired aplastic anemia: outcomes with bone marrow transplantation and immunosuppressive therapy. Ann Intern Med. 1997;126(2):107-15

4. Giralt S, Estey E, Albitar M, van Besien K, Rondón G, Anderlini P, et al. Engraftment of allogeneic hematopoietic progenitor cells with purine analog containing chemotherapy: harnessing graftversus-leukemia without myeloablative therapy. Blood. 1997;89 (12):4531-6.

5. Sorror ML, Maris MB, Storer B, Sandmaier BM, Diaconescu R, Flowers $\mathrm{C}$ et al. Comparing morbidity and mortality of HLAmatched unrelated donor hematopoietic stem cell transplantation after nonmyeloablative and myeloablative conditioning: influence of pretransplantation comorbidities. Blood. 2004;104(4):961-8.

6. Kremens B, Basu O, Grosse-Wilde H, Sauerwein W, Schaefer UW, Havers W. Transplantation of CD34-enriched peripheral stem cells from an HLA-haplotype mismatched donor to a patient with severe aplastic anemia. Bone Marrow Transplant. 2001;27 (1):111-3.

7. Chan KW, Li CK, Worth LL, Chik KW, Jeha S, Shing MK et al. A fludarabine-based regimen for severe aplastic anemia. Bone Marrow Transplant. 2001;27(2):125-8.

8. Vassiliou GS, Webb DK, Pamphilon D, Knapper S, Veys PA. Improved outcome of alternative donor bone marrow transplantation in children with severe aplastic anaemia using a conditioning regimen containing low-dose total body irradiation, cyclophosphamide and Campath. Br J Haematol. 2001;114(3): 701-5.

9. Nishio M, Nakao S, Endo T, Fujimoto K, Takashima H, Sakai T, et al. Successful non-myeloablative stem cell transplantation for a heavily transfused woman with severe aplastic anemia complicated by heart failure. Bone Marrow Transplant. 2001;28(8):783-5.

10. Murotani Y, Kuroda J, Kimura S, Terao K, Fukiya E, Ozawa M et al. Non-myeloablative hematopoietic stem cell transplantation for severe aplastic anemia with various complications. Clin Lab Haematol. 2002;24(5):303-6.

11. Storb R, Deeg HJ, Farewell V, Doney K, Appelbaum F, Beatty P et al. Marrow transplantation for severe aplastic anemia: methotrexate and cyclosporine for prevention of acute graft versus host disease. Blood. 1986;68(1):119-25.

12. Atkinson K, Horowitz MM, Gale RP, van Bekkum DW, Gluckman E, Good RA et al. Risk factors for chronic graft-versus-host disease after HLA-identical sibling bone marrow transplantation. Blood. 1990;75(12):2459-64.

13. Ljungman P. Supportive treatment of patients with severe aplastic anemia. In: Scherezenmeier H and Bacigalupo A, editors. Aplastic Anemia, Pathophysiology and Treatment. Cambridge, Cambridge University Press; 2000:137-153.

14. Ades L, Mary JY, Robin M, Ferry C, Porcher R, Esperou H et al. Long-term outcome after bone marrow transplantation for severe aplastic anemia. Blood. 2004;103(7):2490-7.

15. Horowitz MM. Current status of allogeneic bone marrow transplantation in acquired aplastic anemia. Semin Hematol. 2000;37(1):30-42.
16. Dulley FL, Vigorito AC, Aranha FJ, Sturaro D, Ruiz MA, Saboya R, et al. Addition of low dose busulfan to cyclophosphamide in aplastic anemia patients prior to allogeneic bone marrow transplantation to reduce rejection. Bone Marrow Transplant. 2004;33(1):9-13.

17. Kumar R, Prem S, Mahapatra M, Seth T, Chowdhary DR, Mishra $\mathrm{P}$ et al. Fludarabine, cyclophosphamide and horse antithymocyte globulin conditioning regimen for allogeneic peripheral blood stem cell transplantation performed in non-HEPA filter rooms for multiply transfused patients with severe aplastic anemia. Bone Marrow Transplant. 2006;37(8):745-9.

18. Resnik IB, Aker M, Shapira MY, Tsirigotis D, et al. Allogeneic stem cell transplantation for severe acquired aplastic anaemia using a fludarabine-based preparative regimen. Br J Haematol. 2006;133(6):649-54.

19. Srinivasan R, Takahashi Y, McCoy JP, Spinoza-Delgado I, Dorrance $\mathrm{C}$, Igarashi $\mathrm{T}$ et al. Overcoming graft rejection in heavily transfused and allo-immunised patients with bone marrow failure syndromes using fludarabine-based haematopoietic cell transplantation. Br J Haematol. 2006;133(3):305-14.

20. Gómez-Almaguer D, Vela-Ojeda J, Jaime-Pérez JC, GutiérrezAguirre $\mathrm{CH}$, Cantú-Rodríguez OG, Sobrevilla-Calvo $\mathrm{P}$ et al. Allografting in patients with severe aplastic anemia using peripheral blood stem cells and a fludarabine-based conditioning regimen: the Mexican experience. Am J Hematol. 2006;81(3):157-61.

Avaliação: Editor e dois revisores externos Conflito de interesse: não declarado

Recebido: 31/08/2007

Aceito: 26/09/2007 